\title{
Investigating the Influence of Webinar Participation on Professional Development of English Language Teachers in Rural Vietnam
}

\author{
Tien Mai \\ Ho Chi Minh City Open University, Ho Chi Minh City, Vietnam \\ Michelle Ocriciano \\ University of New South Wales Institute of Languages, Sydney, Australia
}

\begin{abstract}
Professional development plays a central role in fostering teaching quality. As teaching and learning in Vietnam have embraced a digital mode, the emergence of webinars has been noted. However, little is known about its impact on primary and secondary English language teachers, especially in rural areas. This multi-perspective case study aimed to explore the beliefs and practices of a small group of mid-career teachers working at different schools in a southwestern province in Vietnam as they experienced digital professional development. After having reflected on their participation in both synchronous and asynchronous webinars, the teachers were encouraged to implement selected techniques to engage learners in their teaching contexts. Qualitative findings from teachers' interviews and observations demonstrate how this digital modality influenced their pedagogical and social cognition, impacting their classroom practices.
\end{abstract}

Keywords: professional development, webinar, rural contexts, teaching techniques, teacher learning

Among various forms and modes of continuous professional development (PD), attending workshops or conferences is an important activity (Borg, 2014; Wyatt \& Ager, 2017). Borg (2014) verified the multifold benefits for attendees: expanding repertoires of English Language Teaching (ELT) techniques, participating in a network of professionals, and promoting professionalism. Nevertheless, the cost of attending conferences has left communities in some regions marginalized (Canagarajah, 2012), which urges PD decision makers to look for alternatives to face-to-face conferences. In particular, the affordances of web 2.0 have enabled conference organizers to hold webinars (defined as seminars on the Internet by Hockly (2012). Moore, Fisher, and Baber (2016) reported that the IATEFL web conference in 2015 attracted teachers from more than 41 countries. Cost-effectiveness, great convenience, and rich content are factors that appeal to virtual attendees (Harmer, 2015; Peachey, 2012).

Language Education in Asia, 2017, 8(1), 48-66. http://dx.doi.org/10.5746/LEiA/17/V8/I1/A04/Mai_Ocriciano 
The lack of PD opportunities in rural Vietnam is well-documented (Nguyen et al., 2014; Nguyen \& Phung, 2015) but the quality of available teacher training projects is under scrutiny (Nguyen, 2011; Nguyen \& Bui, 2016). Given the emergence of free webinars, this research project was carried out to investigate the benefits and challenges of school teachers when they were invited to train in a virtual learning environment. The study also explored the impact of the participants' implementation of techniques acquired from webinar participation. The project presented qualitative data from interviews and observations of a multi-perspective case study of teachers working in Ben Tre, a rural province of Vietnam.

The paper starts with a literature survey that sheds light on features of effective PD program, affordances that results in the emergence of PD via webinars, and variables that map the PD landscapes in Vietnam. This is followed by a description of the contexts and participants in the multiple-case study as well as methods of data collection and procedures. What the participants learned from the digital training environment and how they implemented new techniques will be revealed in the findings section. Finally, implications of this study at local and other diverse contexts are elaborated.

\section{Literature Review}

\section{Decoding an Effective PD Program}

Concerns over poor quality of in-service teacher training courses were raised in the literature (e.g., Guskey \& Yoon, 2009; Prince \& Barrett, 2014; Stannard \& Matharu, 2014), with Borko (2004) acknowledging that more often than not, PD programs can be "fragmented, [and/or] intellectually superficial" (p. 3). The underlying causes of unsatisfactory training outcomes vary; however, in developing countries, even teacher trainers were not able to set their own effective training agenda owing to the presence of centralized administration (Zein, 2016). Conflicts of interests could not be resolved when PD organizers did not address the needs of local training contexts, asserting their power in both the training curriculum and program implementation to gain financial incentives.

When it comes to effective PD program designs, researchers agree on the substantial variables: content, interaction, collaboration and sustainability. Firstly, the training content and materials should be relevant, situated and school-based with the presence of external expertise (Desimone, 2009; Sahin \& Yildirim, 2015; Stannard \& Matharu, 2014; Walter \& Briggs, 2012; Zein, 2017). Accordingly, instead of a top-down approach in which policy makers inflict a rigid training scheme, participants should have a choice of training materials and modes of participation (Wyatt \& Ager, 2017; Xerri \& Campbell, 2016). In addition, participants are expected to play an active role in discussing and sharing experiences rather than just receiving knowledge from experts (Bates, Phalen \& Moran, 2016; Desimone, 2009; Prince \& Barrett, 2014; Walter \& Briggs, 2012). The program should allow opportunities for on-going support with regards to trainees' implementation of new techniques (Bates et al., 2016; Desimone, 2009; Sahin \& Yildirim, 2015; Walter \& Briggs, 2012). The complicated process of implementation demands constant support to result in teachers' successful uptake (Guskey \& Yoon, 2009). Beyond skills acquisition, participants should be empowered to embark on their self-directed PD journey (Kennedy, 2014). In other words, teachers' personalized development tracks do matter, and the one-size-fits-all PD approach could be neglected. 


\section{Gearing Towards Digital PD}

Concerning the growing popularity of digital PD, Bates et al. (2016) identified elements in which the digital experience benefits participants: immediate solutions to pedagogic problems, external expertise, availability of digital resources and cheaper access but equivalent quality. Additionally, two modes of digital PD were classified: synchronous (real-time interaction) and asynchronous (delayed interactions, happening in different times for different participants) (Bates et al., 2016). Various digital platforms have been utilized across settings: a mobilebased web what showed virtual class tour in Korea (Lee \& Kim, 2016), low-cost mobile phones whose memory cards are copied with class classroom videos in Bangladesh (Woodward, Griffiths, \& Solly, 2014), or screen-casting technology for teachers learning about technology for any digital users (Stannard \& Matharu, 2014). Users' feedback indicated that the videos were "a gold mine" for PD owing to their instructional design and multimodality (Stannard \& Matharu, p. 168). Although the usefulness of digital learning is reported, the sustainability of such platforms are questioned when post-teaching interaction is not sustained (Lee \& Kim, 2016), and when teachers have not achieved mastery level (Woodward et al., 2014).

As regards replacing or supplementing traditional workshops and conferences, webinars can be viewed as a strong contender because they are integrated with digital interaction tools (Harmer, 2015; Hockly, 2012; Peachey, 2012). From the perspective of webinar organizers, careful planning, engaging topics, appropriate interaction, varied tasks, and technical support will increase attendees' participation and motivation (Hockly, 2012). Results of a survey conducted on 122 online participants revealed that $84 \%$ of respondents felt the presentations were successful for their PD (Moore et al., 2016). Noticeably, according to Moore et al., the online conference attendees positively adopted the affordance of synchronous text-based interactions in the digital training environment: "Text chat discourse is at once complex and multifunctional, yet highly cohesive and meaningful" (p. 202). On the other hand, the participants' behavior beyond webinar participation was not reported in Moore et al.'s quantitative study.

\section{Contextualizing Vietnamese Teachers' PD}

Although PD has received attention as a key factor to boost Vietnamese learners' English proficiency in the National Foreign Languages 2020 Project (Nguyen \& Phung, 2015), the quality and availability of top-down PD programs in Vietnam are still in question. School teachers complained that the in-service trainings lacked both relevant content and careful planning (Nguyen, 2011). In disadvantaged areas, few training workshops for English language teachers are accessible, resulting in English teachers' participation in the programs held for those of other subjects (Nguyen et al., 2014). Elsewhere, the training goals were not realistic. Some teachers were dissatisfied since trainers urged them to employ a communicative teaching model regardless of their contexts where the minority students were struggling with learning Vietnamese - their second language (Nguyen \& Bui, 2016).

Several training models have been researched, affirming the value of bottom-up programs in which teachers were the active agents in the changing process. Teachers formed a peer group to provide constructive feedback on each other's works through observations and interviews (Vo \& Nguyen, 2010). Having realized that their working contexts were not conducive to 
quality PD, teachers joined various professional development groups (Nguyen \& Bui, 2016). Most noticeably, teachers in a remote area were able to enact educational innovations by modifying the prescribed curriculum and transforming their practices (Nguyen \& Bui, 2016). However, no studies have been conducted to examine teachers' learning experience via webinars. This study, therefore, aims to fill the gap by reporting on rural teachers' participation in virtual environments. It investigates teachers' attitudes and classroom practices after attending both synchronous and asynchronous webinars.

\section{Contexts and Participants}

\section{Methodology}

In accordance with the sampling method that exploited "personal relationships" suggested by Le (2012), participants were selected purposively rom a cohort of 164 teachers in Ben Tre province in an intensive teacher training project for school English language teachers (consisted of 52 hours of instruction, covering teaching methodologies and technology integration) in which the first researcher was among the five co-trainers in late 2015. After a call for participation was sent to 10 active teachers who maintained frequent post-training communications with the author, four teachers volunteered to participate. These were experienced practitioners who had at least 5 years of teaching experience, working at different primary and secondary state schools in 3 rural districts. All the Vietnamese participants had permanent teaching positions, and achieved the level B2 in The Common European Framework of Reference for Languages. Although all participants are working in a specific province, they provide necessary insights representing Vietnamese school teachers in rural areas on the premise that the centralization of educational policies in Vietnam has been noted (e.g. Nguyen, 2011).

Table 1

Participants' Profile

\begin{tabular}{|l|c|l|c|c|}
\hline Names (Pseudonyms) & Gender & \multicolumn{1}{|c|}{ Position } & $\begin{array}{c}\text { Years } \\
\text { teaching }\end{array}$ & $\begin{array}{c}\text { Learners' } \\
\text { age//grade }\end{array}$ \\
\hline Linh & F & Primary Teacher & 6 & $9 / / 4$ \\
\hline Ha & F & Primary Teacher & 9 & $8 / / 3$ \\
\hline Tam & M & Primary Teacher & 16 & $8 / / 3$ \\
\hline Nhan & M & Secondary Head Teacher & 20 & $12 / / 7$ \\
\hline
\end{tabular}

\section{Data Collection}

Adopting an ethnographic case study design, the main instruments for the project relied on interviews and observation. A few strategies were taken to extract quality data from semistructured interviews, including maintaining an interviewee-centered schedule due to participants' heavy academic workload, making small talk, and using Vietnamese - the interviewees' first language (Le, 2012; Nguyen \& Bui, 2016). The transcription and translation into English was conducted by the first researcher, edited for brevity by the second researcher, and confirmed by the four participants. The second instrument was observation when the 
teachers, acting as the gatekeepers who provided approval and access for the research purpose (Creswell, 2012; Marshall \& Rossman, 2016), agreed on the researcher's visits to their classes with their written consent. The aim of the observation, which was to study implementation of new techniques learned from webinar participation, was made explicit to the participants. Two weeks before their demonstrations, individual observation schedule had been carefully planned at the teachers' convenience. In total, data was drawn from:

- 12 online, individual interviews, reaching approximately 8 hours of recording. The transcription well-exceeded 20000 words.

- 4 observation field notes of 4 classroom teaching lessons. Each lesson lasted 45 minutes.

\section{Procedures}

Three phases were implemented in the research (See Figure 1 and Appendix A). Phase 1 involved introduction to webinars (via email messages), and a tentative schedule to attend the first synchronous webinars in which teachers ticked their preferences from a list of webinars they would like to attend. This ensured that teachers had ownership of their participation, reflecting a bottom-up approach. Drawing on teachers' feedback in Phase 1, the researchers in Phase 2 invited them to view asynchronous webinars (recorded on YouTube) that focused on their identified problematic teaching areas. Both Phase 1 and Phase 2 ended with individual interviews. The final phase entailed teachers' demonstration of new teaching techniques in their contexts, followed by post-teaching interviews in which teachers reflected on their lessons. The final reflection was executed according to Wallace and Woolger (1991)'s postobservation framework:

- procedures: What happened?

- aims: What was achieved?

- alternatives: What could be done differently?

- self-evaluation: What have you learned?

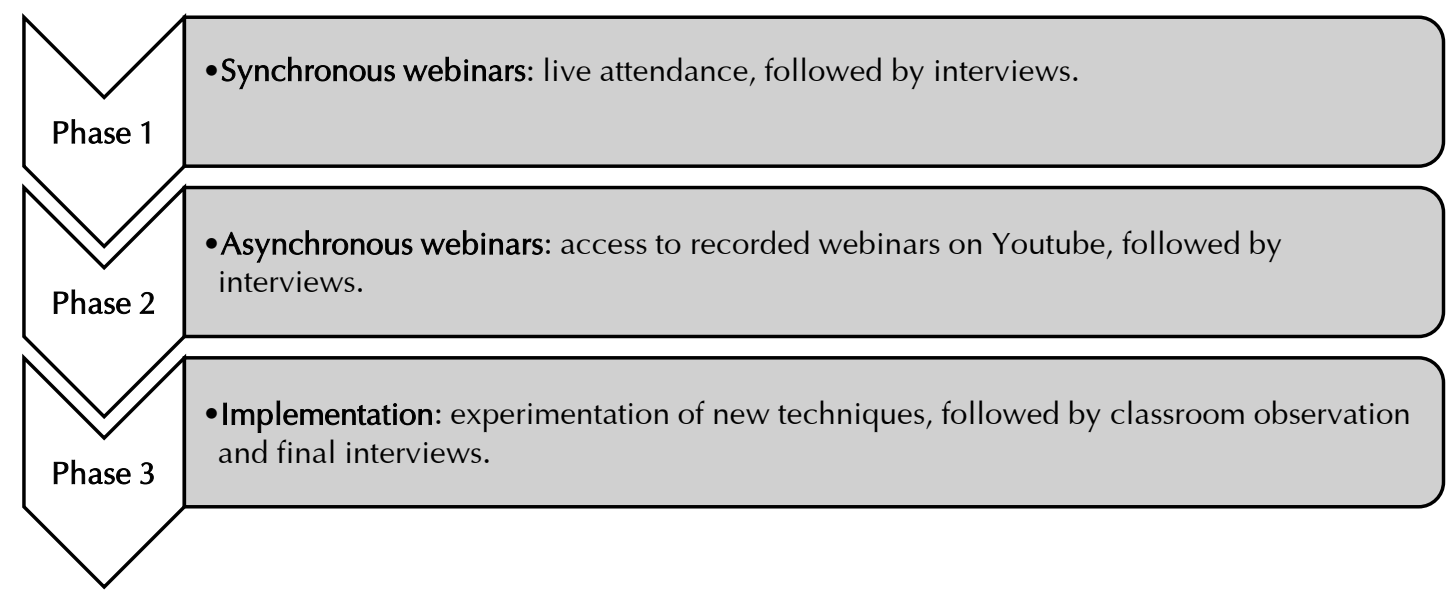

Figure 1: A Summary of Research Procedure 
Each phase is followed by data analysis in which transcriptions of participants' interviews were analyzed, with recurring words being reflected on, coded, and categorized (Saldanã, 2016). Themes were then identified, compared and contrasted among the four participants in all three phases to present an interweaving picture of their digital learning experience. The first researcher maintained a flexible position in the research process, switching between an outsider and a facilitator. As an outsider, he took a non-participant role when observing the teachers in phase 3. As a facilitator, he was involved in guiding teachers' reflections in phase 3. One clear advantage of having the researcher as an insider (facilitator) is that vivid data would be collected (Berger, 2015). The practitioners' reflections on their implementation phase were co-constructed by the first author who drew on his field notes to provide them with multiple perspectives of their classroom practices.

What follows is an account of the key findings, which present emerging themes relating to participants' views on the two modes of webinar participation and their implementation of new techniques.

\section{Findings}

\section{Teachers' Attitudes towards Live and Recorded Webinar Participation}

Access. The four participants did not encounter critical issues with regard to the registration process or webinars log-in. Nonetheless, connectivity and other unexpected incidents might affect participation. As a first-time webinar participant, although Tam could understand the online presentations via following the captions, he suffered a slow connection since his house was far from any signal hotspots. Also, home viewing was disrupted if viewers had external duties, as Ha experienced: "My baby was crying so I had to lull her to sleep. I was trying to focus but unable to grasp everything."

Content. Apart from novel techniques that could be applied in their own teaching contexts, three teachers identified specific aspects of teaching that they had not taken into account prior to webinar attendance: gender equality, low-resource classrooms, and alternative assessment. This is evident in the following quotes:

I haven't paid much attention to gender equality in education (Tam).

The reality is that there are many resources which we're unaware of. Another thing is that teachers and learners are resources themselves, so from this perspective, I need to change my viewpoint (Linh).

After viewing the webinars, I'm aware that I need to develop different assessment forms that do not entirely rely on discrete-item testing (Nhan).

Nevertheless, not every aspect of knowledge the teachers gained from webinars could be effortlessly mastered. In fact, when teachers faced uncertainties, they would link it to their cognitive deficit in the statements below: 
When they use jargon, it's a bit challenging because I'm not often exposed to such language. It's also due to my weak listening ability [laugh] ( $\mathrm{Ha})$.

The definition of creativity is unfathomable (Linh).

The recorded webinars on YouTube enabled me to view many times, but still I was unable to internalize them because I don't often practice listening skills (Linh in Phase 2).

On learning about their challenges, the first researcher extended his role in the project: becoming a collaborator who further explained the difficult realms that the participants faced. In particular, the researcher clarified the webinars' challenging content, discussing each slide which teachers referred to.

Interactivity. The teachers provided contradictory views when comparing and contrasting webinars with traditional training sessions they had attended. Although Ha encountered an unexpected technical experience when using her tablet to view the webinar ("I keyed in a short response, but I forgot to send it."), she felt positive about the chat box function, enthusiastically referring to its social functions: "Some texted content-related messages. Others were like chatting. It's an interesting experience!" As she once had a negative experience attending traditional training sessions ("not daring to stand up or directly asking the teacher"), she preferred the digital mode because "the number of opinions even surpass that of the classroom." On the other hand, Nhan clearly highlighted the advantage of face-to-face interaction: "We interact more in the classroom, joining more teacher-initiated activities, for instance, discussing, pair or group work game. Speaking of webinar interaction, it's more about audio-visual but we haven't really interacted much." He later explained that reviewing the webinar materials is important to internalize the content.

Speakers. The four teachers, having reflected on their roles as digital trainees undertaking serious PD sessions, highly evaluated the training skills of the speakers in Phase 1. Positive comments were salient, ranging from addressing speakers with polite, professional titles such as "the teacher" (Tam) or "the expert" (Nhan) to enjoying their audibility and clarity of expression (Linh). Most importantly, the speaker's training skills in virtual settings received acclaim:

Her pace of delivery was very good. She allowed time for everyone in the group to discuss and then she waited for responses. There was good interaction. When the speaker asked a question, she also observed the responses in the chat box, and then she shared her opinions. She also replied...like a real classroom! (Linh)

Collaboration. Other participants in the webinar community received a wide range of compliments owing to their quick, relevant responses in the chat box: "The way they answered was very professional." (Tam), "They knew the topic very well while it sounded distant to me." (Nhan), and "Other participants worked very fast." (Linh). Beyond such admiration, Ha was 
more practical when she expressed a wish for future collaborative opportunities, stating that she would love to share lesson plans with international teachers. From the perspective of a first-time webinar attendee, Tam described his feeling: "I experienced a little "stage fright". I felt a bit less confident."

\section{The Influence of Webinar Participation on Teaching Practices}

This section reports findings drawn from teachers' reflection in the post-teaching interviews together with the non-participant observation field notes of the first researcher, who continued to act as a collaborator. The researcher's presence in the teachers' classrooms was likely to have caused the observer's paradox despite his non-participant mode, affecting teachers and learners' performance, as Linh admitted: "Class was quiet that day, not as exciting as they used to be." However, it is imperative to note that when such negative impact was raised in the interviews, the first researcher would not facilitate further discussions. The final interviews, therefore, were less directed at guiding teachers to craft a perfectly revised, full-length lesson plan in the future, but more focused on teachers' reflections on their instructional decisions stemmed from the application of new teaching techniques.

In retrospect, the four teachers were satisfied with their application, yet they agreed that major adjustments were to be made to master the new pedagogical techniques. Reflecting on the stage when students took turns asking each other from given question prompts to practice the usage of the modal verb can in an interview activity, Linh felt that "I should have added extra questions in the list because the students finished the interview activity faster than I had planned." The first author suggested that she might have added verbs from previous lessons to recycle the input, and replaced the terminology "ability" written on the board with "can" because a learner had misspelled abylity (sic) when copying the word in his notebook. Her remarks showed that the teacher manual affected her word choice: "If I had written "can", it would have been much easier for students to copy. My mistake was due to the influence of the teacher book in which the author wrote "ability" to explain the usage."

Meanwhile, in Ha's classroom, students formed two large groups to re-order mixed word cards to create meaningful sentences (a word bricks activity). She believed that her classroom management skills could have been refined when there was not shared participation among learners: "To improve it, I think we should form small groups. The groups were quite big, so learners tended to be grabbing their peers' word bricks."

Tam was content with his implementation of gender equality practices, reporting that he had selected students equally to answer his questions. Nevertheless, for subsequent classes, learning from the observation field note (See Appendix B), he agreed that arranging a more gender-mixed seating plan would be effective. In addition, the post-teaching interview enabled him to realize that gender depiction represented in the textbook was not completely fair:

As the picture shows a girl cleaning, it tends to be stereotypical. If it is replaced with a picture showing a boy cleaning, it'll make more sense. They [textbook writers] showed a bit favoritism. In this context, girls often do gentle activities while boys play harder (Tam). 
Nhan's teaching of reading skills involved students' forming groups first, then each member was assigned a specific role including predictor, questioner, clarifier and summarizer (reciprocal teaching). He reflected that the lesson sequence demanded modifications:

Firstly, there should have been instructions regarding components of reciprocal teaching, helping learners to question, clarify, predict and summarize.

Therefore, they could have worked better if I had helped them see their roles better while I might have been playing the instructor or assistant's role (Nhan).

Nhan benefited from the observation field note (See Appendix C) and the post-teaching discussion, revealing how he could have implemented the technique of KWL (What I Know (K), What I Want to Know (W) and What I've Learned (L)) differently in his future lessons when the instructional sequence required a more logical sequence: the vocabulary elicited was written in the two columns $\mathrm{K}$ and $\mathrm{W}$ indistinguishably on the board while the $\mathrm{L}$ column had not been exploited when the lesson ended.

\section{Discussion}

\section{Free Webinars as an Effective Source of PD}

Teachers' remarks appear to show that attending webinars is an effective source for their learning in rural areas because they can expand their repertoires of pedagogical skills at nearly zero cost, which resonates with Moore et al.'s (2016) benefits of attending virtual conferences. When concerns about the lack of resources in rural public schools have been voiced (Nguyen, 2011; Nguyen et al., 2014; Nguyen \& Phung, 2015; Zein, 2016), the general consensus among the participants about the relevance of the webinars' content and the speakers' engaging virtual training skills might offer a practical solution.

Qualitative findings in the study present specific techniques that the participants have acquired, revealing that teachers' ownership of PD should be valued as they have the freedom to select the webinars they would like to attend and the gaps in their teaching they would like to fill. Consistent with teachers in Stannard and Matharu (2014)'s study, who were using free screen casting videos to "develop at their own pace and privately" (p. 167), the recorded webinars in Phase 2 (See Figure 1) encouraged Linh and Ha to adopt multiple viewings while uploaded handouts and slides provided Nhan with further learning opportunities.

As the change of teachers' perceptions in traditional PD programs has been examined (e.g., Borg, 2011), the findings from the teachers mentioned above expand the scope of such changes. Beyond gaining specific techniques from webinar attendance, the rural practitioners articulated the change of their pedagogical perceptions: being aware of resources in difficult classrooms (Linh), promoting gender equality (Tam), and considering alternative assessment (Nhan).

\section{The Role of Facilitated Reflection on the Mastery of New Techniques}

In phases 1 and 2, despite the interesting content, the participants experienced various problems in terms of cognitive and social challenges in the digital community. The rural attendees' learning experience was hindered when it came to certain aspects of pedagogical 
knowledge, leading to further clarification sessions with the first researcher in the post-webinar viewing phases. These findings echoed Prince and Barrett (2014) as they put a heavy emphasis on the alignment of content with teachers' pedagogical competence. Secondly, the interactive features, which form a crucial part of webinars, were not utilized, contrasting with participants of Moore et al. (2016) who regarded interacting digital as a valuable function. Tam, more specifically, found virtual interactivity an unpleasant experience, distancing himself from the community.

The teachers' changes in Phase 3 (See Figure 1) showed that techniques learned from the webinars were actually "implementable" (Prince \& Barrett, 2014, p. 39). Nevertheless, the success of implementation varied among the four teachers possibly due to their struggling efforts to master the content in previous phases. On the other hand, while the four participants were experimenting with the new techniques, the researcher's observation field notes and postteaching interviews provided more insights into the four participants' performance. The collaboration helps better their teaching practices: adding recycled vocabulary to enrich input in the speaking activity (Linh), considering more effective classroom management techniques of the word bricks game $(\mathrm{Ha})$, realizing less salient features of gender inequality depicted in teaching materials (Tam), and carrying out the logical sequence of the KWL technique (Nhan). Webinar viewing alone might not immediately warrant a successful implementation of new approaches. To address the challenges, Nhan stated:

My application did not match the speaker's intentions. I didn't follow the right procedure of the technique KWL. I understand the technique from the webinar but at times it depends on my listening abilities to learn online and to review materials, which is neither deep nor comprehensive.

Nhan's comment in the final discussion re-affirmed the cognitive challenges teachers faced learning in webinars. In light of Wallace (1991)'s reflective model, reflection specified the complexity of "experimental knowledge" - the knowledge that the four participants' gained from their classroom practices regardless of their years of teaching experience. Given that "teaching experience does not automatically translate into teacher expertise" (Farrell, 2013, p. 1080), the post-teaching dialogue with the first author has engaged the participants in an active and conscious reflection activity. Hence, post-webinar viewing acknowledges the presence of facilitators or collaborators when teachers "need just-in-time, job-embedded assistance as they struggle to adapt new curricula and new instructional practices to their unique classroom contexts" (Guskey \& Yoon, 2009, p. 498).

\section{Implications for Other Educational Contexts}

With respect to free resources for personal PD, the project can further inform other teachers or teacher educators of the availability and the relevance of live and recorded webinars.

Attendance in this digital training mode could add dimensions to their pedagogical repertoires once they are familiar with webinar components such as registration and log-in procedures, chat box and presentation handouts for post-webinar implementation and reflection. 
PD providers for teachers in rural areas should be aware of the efficacy of this emerging training platform. Webinar participation should be integrated into or might even replace the traditional track of taking face-to-face training sessions when it comes to cost-saving factors, flexible schedule and individualized content. Modes of participation are synchronous and/or asynchronous, which can best fit the participants' working schedule and identified areas for development. Inviting in-service teachers to participate in free webinars, in other words, can be the very first step to prepare them for "professional autonomy" (Kennedy, 2014, p. 349). If implemented, the approach tends to downplay the centralized and bureaucratic policies of PD programs observed in developing contexts (e.g. Zein, 2016). Likewise, conference organizers should consider posting conference talks online, activating digital views of teachers, especially those in remote or rural regions who are unable to attend the conferences in person due to constraints such as finance and distance to the meeting venue (Nguyen, 2011). From a practical perspective, when Internet access is not reliable or available, recorded webinars or conference talks can be copied to participants' USB drives or their mobile phones' memory cards for home or mobile-based viewing - the practice of which has been found useful according to Woodward et al. (2014).

In light of the complicated process of the application of new techniques, it is crucial that offline support is given when teachers are learning online, including technical assistance and content clarification. This can be achieved by involving collaborators - who could be colleagues at the same school to facilitate teachers' "emergent mastery" (Nguyen \& Bui, 2016, p. 97). Similarly, moving beyond the finite hours of one-off conferences, it underscores the need to have locally made webinars hosted by presenters who share the first language with participants to facilitate in-depth discussions relating to new knowledge acquisition, and are capable of providing continuing support to sustain trainees' development. This emphasizes the establishment of local communities of practice of webinar goers to encourage active webinar participation and reflection on the implementation of novel techniques.

\section{Limitation and Future Direction}

The project limitations should be noted regarding the sustainability of webinar participation and learners' outcome. Firstly, as the project was conducted on a four-month period, the overgeneralization of the research findings should be carefully reviewed, requiring a long-term investigation into the impact of webinar attendance. The second consideration is linked to learners' outcome, which has not been measured apart from teachers' self-reported data in conjunction with the researcher's observation field notes. We are uncertain whether learners have really benefited from teacher change after their teachers' webinar attendance. That said, future studies might be conducted to analyze the effect of webinar attendance with a longitudinal focus, integrated with a reliable assessment tool to evaluate the impact of teacher digital PD on learners' progress.

\section{Conclusion}

The experience of four school teachers' participating in free webinars has appeared to be beneficial for their informal PD. Simultaneously, it depicts the complex processes that teachers have undergone in virtual environments, which question their theoretical knowledge and professionalism within the webinar community. Secondly, the digital participation has enabled 
them to trial new techniques in their own teaching contexts, albeit at varying degrees of success. The follow-up implementation reflections were facilitated by the first researcher's collaboration, which provides another perspective into their practices. When local facilitators are involved, attending webinars should be considered as an acceptable alternative to costly traditional face-to-face conferences for teachers working in rural areas, especially those who are equipped with basic technological devices. PD decision-makers in the National Foreign Languages 2020 Project (Nguyen \& Phung, 2015) and in other large-scale PD initiatives, as a result, are advised to integrate the affordances of the webinar platform with local facilitators' expertise to design effective PD programs that best serve the needs and contexts of rural participants.

\section{Acknowledgement}

We would like to thank Dr. Subhan Zein and 3 other anonymous reviewers for their invaluable comments that greatly improved our manuscript.

\section{Author Note}

Tien Mai, Faculty of Foreign Languages, Ho Chi Minh City Open University, Ho Chi Minh City, Vietnam; Michelle Ocriciano, University of New South Wales Institute of Languages, Sydney, Australia.

Tien Mai is a lecturer of English at HCMC Open University and a teacher trainer at IEI, VNUHCMC. He holds an M.A in applied linguistics from Curtin University. He has achieved PD awards from American English State, Cambridge English and The Consultants-E. His research interests include CALL and Teacher PD.

Michelle Ocriciano is an EAP teacher and teacher trainer at UNSW Institute of Languages. She has been teaching for 18 years in Brazil, the United States and Australia. She holds an MA in Technology in Language Teaching. Her fields of interest are Technology in Language Teaching and Teacher PD.

Acknowledgements: The research is sponsored by CamTESOL Regional ELT Research Grants 2016.

Correspondence concerning this article should be addressed to Tien Mai, Faculty of Foreign Languages, HCMC Open University, Room 503, 35-37 Ho Hao Hon St., District 1, Ho Chi Minh City, Vietnam. E-mail: tienmaiminh@yahoo.com 


\section{References}

Bates, M. S., Phalen, L., \& Moran, C. (2016). Online professional development: A primer. Phi Delta Kappan, 975), 70-73. https://doi.org/10.1177/0031721716629662

Berger, R. (2015) Now I see it, now I don't: Researcher's position and reflexivity in qualitative research. Qualitative Research, 15(2), 219-234. https://doi.org/10.1177/1468794112468475

Borg, S. (2011). The impact of in-service teacher education on language teachers' beliefs. System, 39(3), 370-380. https://doi.org/10.1016/j.system.2011.07.009

Borg, S. (2014). The benefits of attending ELT conferences. ELT Journal, 69(1), 35-46. https://doi.org/10.1093/elt/ccu045

Borko, H. (2004). Professional development and teacher learning: Mapping the terrain. Educational Researcher, 33(8), 3-15. https://doi.org/10.3102/0013189X033008003

Canagarajah, A. S. (2012). Teacher development in a global profession: An autoethnography. TESOL Quarterly, 46(2), 258-279. https://doi.org/10.1002/tesq.18

Creswell, J. (2012). Educational research: Planning, conducting, and evaluating quantitative and qualitatuve research (4th ed.). Boston, MA: Pearson Education, Inc

Desimone, L. M. (2009). Improving impact studies of teachers' professional development: Toward better conceptualizations and measures. Educational Researcher, 38(3), 181 199. https://doi.org/10.3102/0013189X08331140

Farrell, T. S. C. (2013). Reflecting on ESL teacher expertise. System, 41(4), 1070-82. https://doi.org/10.1016/j.system.2013.10.014

Guskey, T. R., \& Yoon, K. S. (2009). What works in professional development. Phi Delta Kappan, 907), 495-500. https://doi.org/10.1177/003172170909000709

Harmer, J. (2015). The practice of English language teaching (5th ed.). Harlow, UK: Pearson Education Limited

Hockly, N. (2012). Webinars: A cookbook for educators. Retrieved from http://theround.com/resource/webinars-a-cookbook-for-educators/

Kennedy, A. (2014) Models of Continuing Professional Development: A framework for analysis. Professional Development in Education, 40(3), 336-351. https://doi.org/10.1080/19415257.2014.929293

Le, V. C. (2012). Interviews. In R. Barnard \& A. Burns (Eds.), Researching language teacher cognition and practice: International case studies (pp. 90-102). Bristol, UK: Multilingual Matters

Lee, J.-H., \& Kim, H. (2016). Implementation of SMART teaching 3.0: Mobile-based selfdirected EFL teacher professional development. The Journal of AsiaTEFL, 13(4), 331 346. https://doi.org/10.18823/asiatefl.2016.13.4.6.331

Marshall, C. \& Rossman, G. (2016). Designing qualititative research. (6th ed.). Los Angeles, CA: Sage.

Moore, C., Fisher, T., \& Baber, E. (2016). Virtually unknown: Teacher engagement in an online conference. ELT Journal, 7O2), 200-211. https://doi.org/10.1093/elt/ccw003

Nguyen, C. D., Le, T. L., Tran, H. Q., \& Nguyen, T. H. (2014). Inequality of access to English language learning in primary education in Vietnam. In H. Zhang, P. W. K. Chan, \& C. Boyle (Eds.), Equality in education: Fairness and inclusion (pp. 139-153). Rotterdam: SensePublishers 
Nguyen, H., \& Bui, T. (2016). Teachers' agency and the enactment of educational reform in Vietnam. Current Issues in Language Planning, 171), 88-105. https://doi.org/10.1080/14664208.2016.1125664

Nguyen, H. T. M. (2011). Primary English language education policy in Vietnam: Insights from implementation. Current Issues in Language Planning, 12(2), 225-249. https://doi.org/10.1080/14664208.2011.597048

Nguyen, T. P. L., \& Phung, N. T. (2015). Innovation in English language education in Vietnam for ASEAN 2015 integration: Current issues, challenges, opportunities, investments, and solutions. In R. Stroupe \& K. Kimura (Eds.), ASEAN integration and the role of English language teaching (pp. 104-120). Phnom Penh, Cambodia: IDP Education. Retrieved from http://tinyurl.com/yaqobjwd

Peachey, N. (2012, November). Teacher development online. English Teaching Professional, 83, pp. 4-6

Prince, E.-S., \& Barrett, A. (2014). Continuing professional development in action: An Indian experience. In D. Hayes (Ed.), Innovations in the continuing professional development of English language teachers (pp. 19-44). London, UK: British Council.

Saldanã, J. (2016). The coding manual for qualitative researchers (3rd ed.). Los Angeles, CA: Sage

Sahin, I., \& Yildirim, A. (2015). Transforming professional learning into practice. ELT Journal, 703), 241-252. https://doi.org/10.1093/elt/ccv070

Stannard, R., \& Matharu, S. (2014). Using technology to provide greater flexibility and access to continuing professional development. In D. Hayes (Ed.), Innovations in the continuing professional development of English language teachers (pp. 159-178). London, UK: British Council

Vo, L.T. \& Nguyen, T.M.H. (2010). Critical Friends Group for EFL teacher professional development. ELT Journal, 64(2), 205-213. https://doi.org/10.1093/elt/ccp025

Wallace, M., \& Woolger, D. (1991). Improving the ELT supervisory dialogue: The Sri Lankan experience. ELT Journal, 45(4), 320-327. https://doi.org/10.1093/elt/45.4.320

Wallace, M. J. (1991). Training foreign language teachers: A reflective approach. Cambridge, UK: Cambridge University Press

Walter, C., \& Briggs, J. (2012). What professional development makes the most difference to teachers? Oxford: University of Oxford Department of Education. Retrieved from http://tinyurl.com/ycpcev9x

Woodward, C., Griffiths, M., \& Solly, M. (2014). English in Action: A new approach to continuing professional development through the use of mediated video, peer support and low-cost mobile phones in Bangladesh. In D. Hayes (Ed.), Innovations in the continuing professional development of English language teachers (pp. 227-248). London, UK: British Council

Wyatt, M., \& Ager, E. O. (2017). Teachers' cognitions regarding continuing professional development. ELT Journal, 71(2), 171-185. https://doi.org/10.1093/elt/ccw059

Xerri, D., \& Campbell, C. (2016). E-portfolios in teacher development: The better option? ELT Journal, 70(4), 392-400. https://doi.org/10.1093/elt/ccw032 
Zein, M. S. (2016). Factors affecting the professional development of elementary English teachers. Professional Development in Education, 42(3), 423-440.

https://doi.org/10.1080/19415257.2015.1005243

Zein, M. S. (2017). Professional development needs of primary EFL teachers: Perspectives of teachers and teacher educators. Professional Development in Education, 43(2), 293 313. https://doi.org/10.1080/19415257.2016.1156013 


\section{Appendix A}

\section{A Description of Webinars Attended in Phase 1-2, and Techniques Implemented in Phase 3}

\section{Phase 1: Synchronous viewing}

\begin{tabular}{|c|c|c|c|c|}
\hline Title & Organizers & Presenters & Access Links & Attendees \\
\hline $\begin{array}{l}\text { Teaching Teenagers } \\
\text { Creatively }\end{array}$ & $\begin{array}{l}\text { Oxford } \\
\text { University } \\
\text { Press (OUP) }\end{array}$ & Maria Byrne & $\begin{array}{l}\text { Access with an Oxford } \\
\text { Premium Account at } \\
\text { tinyurl.com/h7pbnv5 }\end{array}$ & Linh \\
\hline $\begin{array}{l}\text { A Framework for } \\
\text { Communicative } \\
\text { Speaking }\end{array}$ & OUP & Tony Prince & $\begin{array}{l}\text { Access with an Oxford } \\
\text { Premium Account at } \\
\text { tinyurl.com/h7pbnv5 }\end{array}$ & Nhan \\
\hline $\begin{array}{l}\text { Classroom } \\
\text { Management with Five } \\
\text { Adaptable Forms }\end{array}$ & $\begin{array}{l}\text { American } \\
\text { English (AE) }\end{array}$ & $\begin{array}{l}\text { Catherine } \\
\text { Thomas }\end{array}$ & tinyurl.com/hx9zc4r & $\begin{array}{l}\text { Linh } \\
\text { Nhan }\end{array}$ \\
\hline $\begin{array}{l}\text { Promoting Gender } \\
\text { Equality in the English } \\
\text { Language Classroom }\end{array}$ & $\mathrm{AE}$ & Philip Dierking & tinyurl.com/glvzxyx & Tam \\
\hline $\begin{array}{l}\text { Creating and } \\
\text { Sustaining } \\
\text { English Language } \\
\text { Clubs } \\
\text { to Enhance EL }\end{array}$ & $\mathrm{AE}$ & $\begin{array}{l}\text { Kathleen Malu } \\
\text { and Bryce } \\
\text { Smedley }\end{array}$ & tinyurl.com/ju5roth & $\mathrm{Ha}$ \\
\hline
\end{tabular}

\section{Phase 2: Asynchronous viewing}

\begin{tabular}{|l|l|l|l|l|}
\hline \multicolumn{1}{|c|}{ Title } & Organizers & Presenters & Access Links & Attendees \\
\hline $\begin{array}{l}\text { Reciprocal Teaching } \\
\text { Reading Strategies }\end{array}$ & $\mathrm{AE}$ & Dr. Rob Danin & tinyurl.com/gssx2rz & Nhan \\
\hline $\begin{array}{l}\text { Easy Reading } \\
\text { Activities to Engage } \\
\text { Students }\end{array}$ & $\mathrm{AE}$ & $\begin{array}{l}\text { Serena Chu- } \\
\text { Mraz }\end{array}$ & tinyurl.com/hmkfz6l & Nhan \\
\hline $\begin{array}{l}\text { Games for Learning } \\
\text { AE }\end{array}$ & $\mathrm{AE}$ & $\begin{array}{l}\text { Jennifer } \\
\text { Hodgson and } \\
\text { Kevin } \\
\text { McCaughey }\end{array}$ & tinyurl.com/hs3o2hs & Ha \\
\hline $\begin{array}{l}\text { Maker Space: The Low } \\
\text { Resource Classroom }\end{array}$ & Dr. Nellie & $\begin{array}{l}\text { Kirsten } \\
\text { Waechter and } \\
\text { Julie Pratten }\end{array}$ & tinyurl.com/hjwcgz5 & Linh \\
\hline $\begin{array}{l}\text { They talk too fast! } \\
\text { Helping students with } \\
\text { listening }\end{array}$ & Cambridge & Chris Redston & tinyurl.com/hszhqpk & Tam \\
\hline
\end{tabular}




\section{Phase 3: Techniques implemented}

\begin{tabular}{|c|l|}
\hline \multicolumn{1}{|c|}{ Teachers } & \multicolumn{1}{c|}{ Techniques } \\
\hline Linh & $\begin{array}{l}\text { Interview: a speaking, class mingling activity. Students take turns asking each other } \\
\text { based on given prompts. } \\
\text { (From Classroom Management with Five Adaptable Forms webinar) }\end{array}$ \\
\hline Ha & $\begin{array}{l}\text { Word Bricks: teachers need to prepare word cards, which then are jumbled. Students } \\
\text { form groups to put the words in the correct order to create meaningful sentences. } \\
\text { (From Games for Learning American English webinar) }\end{array}$ \\
\hline Tam & $\begin{array}{l}\text { Gender Equality: creating a gender-neutral classroom by designing activities that do not } \\
\text { favor any gender and investigating course books to see if there is gender quality. }\end{array}$ \\
& $\begin{array}{l}\text { From Promoting Gender Equality in the English Language Classroom webinar) } \\
\text { Nhan } \\
\text { Reciprocal Teaching: students form groups, then members are assigned a role: } \\
\text { predictor (guess the content of the reading based on prompts such as titles, headings, } \\
\text { etc.; questioner (ask questions relating to the content); clarifier (provide answers with } \\
\text { evidence from the text); and summarizer (give a synopsis of the reading text or group } \\
\text { discussion). } \\
\text { (From Reciprocal Teaching Reading Strategies webinar) } \\
\text { KWL Chart: a graphic organizer consisting of 3 columns to help students' reflections: } \\
\text { What I Know (K), What I Want to Know (W), and What I Learn (L) } \\
\text { (From Easy Reading Activities to Engage Students webinar) }\end{array}$ \\
\hline
\end{tabular}




\section{Appendix B}

An Excerpt from the Observation Field Note of Teacher Tam: Class Seating Plan

Visitor and report writer: Tien MAI

Teacher: Tam

No. of Learners: 24

Place: Ba Tri, Ben Tre
Course book: English 3

Unit 5: Are they your friends

Page: 30

Time: 8:30-9h10

Date: Thursday, 29/09/2016

Note:

- F: Female

- M: Male

- An empty block indicates an empty seat.

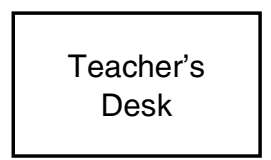

\begin{tabular}{|l|l|l|l|}
\hline $\mathbf{F}$ & $M$ & $M$ & $\mathbf{F}$ \\
\hline$M$ & & $M$ & $M$ \\
\hline$M$ & $M$ & $F$ & \\
\hline$M$ & & $M$ & \\
\hline
\end{tabular}

\begin{tabular}{|l|l|l|l|}
\hline $\mathbf{F}$ & $\mathbf{F}$ & $\mathbf{F}$ & $\mathbf{F}$ \\
\hline $\mathbf{F}$ & $\mathbf{F}$ & $\mathbf{F}$ & $\mathrm{M}$ \\
\hline$M$ & $\mathbf{F}$ & & $\mathrm{M}$ \\
\hline$M$ & & & \\
\hline
\end{tabular}




\section{Appendix C}

\section{An Excerpt from the Observation Field Note of Teacher Nhan: Lesson Stages}

Visitor and report writer: Tien MAI

Teacher: Nhan

Course book: English 7

Unit 4: At School (Part 6: Read)

Pages: 44,45

No. of Learners: 35

Time: 1:35-2:15

Place: Mo Cay Bac, Ben Tre

Date: Thursday, 29/09/2016

T: Teacher

SS: Students

\begin{tabular}{|c|c|}
\hline Time/Stage Aim & Activities \\
\hline 1:43 Lead-in & $\begin{array}{l}\text { T says "Today we learn about school in the USA. Cung cấp thông tin về trường ở } \\
\text { Mỹ." (Today we're learning about schools in the USA. We'll be provided with } \\
\text { information about American schools) } \\
\text { T gives instructions: "Chúng ta kẻ làm } 3 \text { cột." (We're drawing a three-column } \\
\text { table) }\end{array}$ \\
\hline $\begin{array}{l}\text { 1:44 Activating prior } \\
\text { knowledge }\end{array}$ & $\begin{array}{l}\text { T writes on the board: KWL } \\
\text { (What I know/What I want to know/What I have learned) } \\
\text { T gives instructions "Đọc lướt qua đoạn văn những cụm từ nào em đã từng biết." } \\
\text { (Skim the text, what words have you learned?) } \\
\text { T asks "School in the US có gì?" (What do U.S schools have?) } \\
\text { - Ss answer "They wear uniform." } \\
\text { T writes uniform on the board. } \\
\text { T asks "Học sinh nước ngoài có ra chơi không?" (Do foreign students have break } \\
\text { time?) } \\
\text { T writes "break" on the board. } \\
\text { T gives instructions "Các bạn đọc lướt tiếp, xem các bạn đã biết gì?" (Please } \\
\text { continue skimming, what have you know?) } \\
\text { - Ss answered "cafeteria" } \\
\text { T asks "đó là gì?"(What is it?) and then answers "căng tin" (cafeteria) } \\
\text { T writes "cafeteria" on the What I want to know column }\end{array}$ \\
\hline 1:51 Close reading & $\begin{array}{l}\text { T moves around to monitor } \\
\text { - Ss ask questions about the meanings of "popular, baseball, snacks". } \\
\text { Teacher asks some students to translate and then writes "baseball" on What I } \\
\text { Know column and "snacks" on What I want to know }\end{array}$ \\
\hline
\end{tabular}

